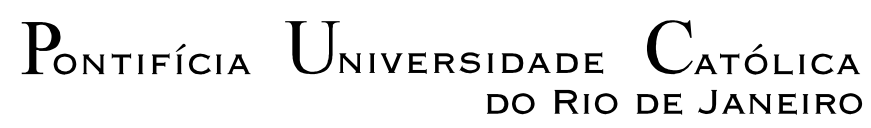

DO RIO DE JANEIRO

Ezra Shane Spira-Cohen

O movimento ambientalista em suas arenas discursivas: participação do Brasil e EUA nas conferências da ONU

Dissertação apresentada como requisito parcial para obtenção do título de Mestre pelo Programa de PósGraduação em Sociologia e Política da PUC - Rio.

Orientadora: Profa. Angela Maria de Randolpho Paiva 


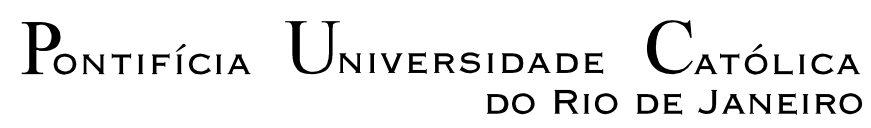

DO RIO DE JANEIRO

Ezra Shane Spira-Cohen

\section{O movimento ambientalista em suas arenas discursivas: participação do Brasil e EUA nas conferências da ONU}

Dissertação apresentada como requisito parcial para obtenção do título de Mestre pelo Programa de PósGraduação em Ciências Sociais da PUC-Rio. Aprovada pela Comissão Examinadora abaixo assinada.

Profa. Angela Maria de Randolpho Paiva

Orientadora

Departamento de Sociologia e Política - PUC-Rio

Prof. Liszt Benjamin Vieira Departamento de Direito - PUC-Rio

Profa. Maria Sarah da Silva Telles

Departamento de Sociologia e Política - PUC-Rio

Prof. Valter Sinder Departamento de Sociologia e Política - PUC-Rio

Profa. Mônica Herz

Coordenadora Setorial do Centro de Ciências Sociais - PUC-Rio

Rio de Janeiro, 21 de outubro de 2011. 
Todos os direitos reservados. É proibida a reprodução total ou parcial do trabalho sem autorização da universidade, da autora e do orientador.

\section{Ezra Shane Spira-Cohen}

Graduou-se em Desenvolvimento Comparativo e língua espanhola pelo Trinity College de Hartford, Connecticut EUA. Nativo dos Estados Unidos estuda o Brasil e outros países da América Latina de forma comparada.

Ficha Catalográfica

Spira-Cohen, Ezra Shane

O movimento ambientalista em suas arenas discursivas: participação do Brasil e EUA nas conferências da ONU / Ezra Shane Spira-Cohen ; orientadora: Angela Maria de Randolpho Paiva. - 2011. $131 \mathrm{f}$; $30 \mathrm{~cm}$

Dissertação (mestrado)-Pontifícia Universidade Católica do Rio de Janeiro, Departamento de Sociologia e Política, 2011.

Inclui bibliografia

1. Sociologia - Teses. 2. Meio ambiente. 3. Sociedade civil. 4. Esfera pública. 5. Desenvolvimento. I. Paiva, Angela Maria de Randolpho Paiva. II. Pontifícia Universidade Católica do Rio de Janeiro. Departamento de Sociologia e Política. III. Título.

CDD: 301 
Em memória de Ziggy Spira 


\section{Agradecimentos}

Aos meus pais, Roy e Eileen, pelo amor, apoio e confiança incondicional. Aos meus irmãos, Ariel e David, por seu exemplo encorajador, e por me incentivar a realizar êxito acadêmico.

À Ângela Paiva, obrigado por ter desenvolvido essa dissertação comigo. Sem sua orientação e tempo esse trabalho não teria sido realizado. Seu entusiasmo e conhecimento foi uma inspiração que eu espero levar comigo para o futuro. Obrigado pela paciência, as conversas, as correções e por ter compreendido ambas minhas limitações e minhas aspirações.

À PUC-Rio, pelos auxílios concedidos, sem os quais este trabalho não poderia ter sido realizado.

Aos membros da banca, Liszt Vieira, Sarah da Silva Telles e Valter Sinder. Suas áreas de conhecimento e sua participação no meu exame de qualificação foram fundamentais para a realização desse projeto. Obrigado pela atenção, ideias e críticas que prepararam meu caminho.

Aos professores do departamento de Sociologia e Política da PUC por suas aulas, por compartilhar seu conhecimento, e por uma experiência sem preço.

À Ana, Mônica e Carla por ajudar um estrangeiro muitas vezes perdido e por oferecer belas dicas para facilitar a navegação burocrática da vida acadêmica.

A todos que me ajudaram desenvolver minha habilidade de redação: ao Jonas Lana por sua amizade, à Alessandra Maia por seu apoio, à Marcele e Guilherme por se terem disposto durante os momentos finais deste projeto. 


\section{Resumo}

Spira-Cohen, Ezra Shane; Paiva, Angela Maria de Randolpho. O movimento ambientalista em suas arenas discursivas: participação do Brasil e EUA nas conferências da ONU. Rio de Janeiro 2008. 131p. Dissertação de Mestrado - Departamento de Sociologia e Política, Pontifícia Universidade Católica do Rio de Janeiro.

Esta dissertação examina o surgimento do movimento ambientalista como parte de um processo maior de conscientização sobre a proteção do meio ambiente. Observa como, através da abertura de espaço discursivo para a participação democrática, as conferências internacionais da ONU sobre o meio ambiente em 1972 e 1992 contribuíram para a formação deste movimento e o próprio conceito do meio ambiente. A discussão utiliza-se dos conceitos que Jürgen Habermas desenvolve na sua teoria de ação comunicativa para destacar a importância da esfera pública e o papel da sociedade civil neste processo. No entanto, a partir de uma comparação da participação do Brasil e os EUA nas duas conferências da ONU, coloca em questão o uso dessa teoria para explicar a atuação desses países e as mudanças ao longo das duas décadas que separaram as conferências. Levanta uma discussão metodológica, inspirada em ideias apresentadas por Michel Foucault, que permite uma análise do surgimento do movimento ambientalista no Brasil e os EUA. Para além disso, contextualiza a participação de ambos os países nas conferências internacionais e a mudança para do foco para o desenvolvimento. Através disso, salienta as tensões entre as perspectivas de Habermas e Foucault, discutindo seus limites e contribuições para esta análise.

\section{Palavras-Chave}

Meio Ambiente; sociedade civil; esfera pública; desenvolvimento. 


\section{Abstract}

Spira-Cohen, Ezra Shane; Paiva, Angela Maria de Randolpho (Advisor). The Environmental Movement in its Discursive Arenas: The Participation of Brazil and the USA in UN Conferences. Rio de Janeiro 2008. 131p. Masters Dissertation - Departament of Sociologia e Política, Pontifícia Universidade Católica do Rio de Janeiro.

This thesis examines the emergence of the environmental movement as part of a larger process of increasing conscientiousness about environmental protection. It looks at how the international UN conferences on the environment in 1972 and 1992 contributed to the formation of this movement, and the concept of the environment, by opening discursive space and allowing for democratic participation. The discussion uses concepts developed by Jürgen Habermas, in his theory of communicative action, to highlight the importance of the public sphere and the role of civil society in this process. However, a comparison of the participation of Brazil and the USA in the two conferences raises questions about the application of this theory. In order to explain the activity of these countries and the changes that occurred during the 20 years that separate the conferences a different perspective is presented. Ideas inspired by Michel Foucault provide a methodological discussion, which permits an analysis of the emergence of the environmental movement in Brazil and the USA. In addition, it contextualizes their participation in the international conferences and helps understand the turn in the international community towards a focus on development. Finally, as a result of the tensions that arise between Habermas and Foucault's perspectives, the limits and contributions of these authors for the herein analysis are uncovered.

\section{Keywords}

Environment; Civil Society; Public Sphere; Development. 


\section{Sumário}

1. Introdução 9

1.1. O movimento ambientalista $\quad 15$

1.2. Os discursos ambientalistas 20

$\begin{array}{ll}\text { 1.3. A ecopolítica } & 24\end{array}$

1.4. A sociedade civil internacional 29

1.5. O Espaço público 33

1.6. A esfera pública internacional 37

2. O movimento ambientalista em suas arenas discursivas 41

2.1. As origens das conferências ambientalistas 43

2.2. A Conferência das Nações Unidas sobre o Meio Ambiente Humano (UNCHE) $\quad 47$

2.3. A Conferência das Nações sobre Meio Ambiente e Desenvolvimento (UNCED)

2.4. Vinte anos para frente. O que mudou? 70

3. A formação das arenas discursivas $\quad 74$

3.1. A crise ambiental no Brasil e nos EUA 79

3.2. A institucionalização do movimento ambientalista no Brasil e nos EUA

3.3. O movimento ambientalista no Brasil e nos EUA 97

3.4. A participação do Brasil e os EUA nas Conferências da ONU

3.5. O futuro do movimento ambientalista nas suas arenas discursivas

4. Considerações finais 